\title{
Flipped Classroom Using Screencast-O-Matic Apps in Teaching Reading Skill in Indonesian Language
}

\author{
Hasanudin, C. ${ }^{1}$, Fitrianingsih, A. ${ }^{2}$ \\ ${ }^{1}$ Indonesian Language and Literature Department, Faculty of Language Education and Art, IKIP \\ PGRI Bojonegoro, East Java, Indonesia, ${ }^{2}$ English Language Education IKIP PGRI Bojonegoro \\ Corresponding email : cahyo.hasanudin@ikippgribojonegoro.ac.id
}

\begin{abstract}
This article aims to describe the implementation of the flipped classroom method using Screencast-O-Matic apps in the teaching of Indonesian language reading skills and the impact this method has on the learning process. This qualitative research was conducted at one of the private institutes in Bojonegoro, Indonesia, and the researcher acted as the observer. The data were obtained through interviews, classroom observations, and document analysis, and were analysed using Creswell's thematic analysis, which involves six stages of analysing and intrepreting. Then, the data were validated using triangulations of theory and source. The results of this research show that Screencast-O-Matic apps contribute to the successful implementation of the flipped classroom method. The combination of the teaching method and the media creates innovation in teaching reading skills in the Indonesian language. In the teaching and learning process, the teacher acts as the facilitator, resulting in some good impacts for the students: 1) the students are motivated by the video study materials, 2) the students are able to enjoy their leisure time, 3 ) the students are pleased with the teaching and learning process and are able to answer questions quickly, 4) the students appreciate each other's opinions, and 5) the students have more comprehensive knowledge of the Indonesian language reading skills materials.
\end{abstract}

Keywords: flipped classroom; Screencast-O-Matic; reading skills in the Indonesian language

DOI: $10.20961 /$ ijpte.v2i0.25356

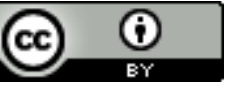

Except where otherwise noted, content on this site is licensed under a Creative Commons Attribution 4.0 International License. 


\section{INTRODUCTION}

In the $21^{\text {st }}$ century, the field of education is affected greatly by developed technologies. For this reason, a qualified education system should not limit learning but transform the traditional structure into a modern structure utilising technological opportunities (Rakhmetullina, Uvaliyeva, \& Nugumanova, 2014).

Traditionally, teaching in some private institutes is dominated by teacher-centred methods. However, some teachers and education practitioners use many strategies to foster active learning. Evidence can now be found throughout the research that active learning is an effective means for student learning and engagement, and it now has robust support from education researchers, funding agencies, public policy makers and institutions (Braun, Bremser, Duval, Lockwood, \& White, 2017). One such active learning strategy is the flipped classroom method.

The flipped classroom method was first introduced by Bergmann and Aaron in 2007. Since then, many researchers have examined its impact on teaching. Generally, the flipped classroom method inverts traditional classroom teaching. This means that the students have to read or study at home, so the teacher does not need to explain the study materials in the classroom. Then, the students carry out assignments in the class.

The main aims of a flipped classroom according to Chandra and Yulius (2016: 16) are: 1) to devote more time in classroom to assimilating the materials in the form of exercises, or other activities, and 2) to accommodate the differences in the students' levels of motivation, understanding, and previous knowledge.

According to Johnson (2013), the flipped classroom is a strategy used by teachers to minimise direct instruction and maximise the teacher-student interactions. This stratey utilises technology that supports online materials.

Tarigan (2008: 7-8) says that reading is a process carried out by readers to obtain information provided by the writer through his written language. Additionally, reading can be considered a process of understanding the written word.

The researcher finds that the Indonesian Education Department has implemented the flipped classroom method in the process of teaching and learning reading skills. Based on the results of the interviews, the researcher believes that the students are really motivated and eager to be active in their learning. In their opinion, students feel bored with the traditional teaching approach, in which the teacher always gives direct instruction. The flipped classroom helps some students to enjoy studying.

The equipment that can be used to produce and broadcast lecture videos are Screencast-O-Matic, Camtasia PC, TechSmith Relay, Office Mix, and Adobe Presenter (Ozdamli \& Asiksoy, 2016). In this case, the teacher uses Screencast-OMatic Apps in implementing his flipped classroom. This combination is expected to contribute to developing good reading skills among the students of the Indonesian Education Department. As such, it could increase innovation in language teaching.

Screencast-O-Matic Apps is a Java-based application media that is used to make screencasts in Windows, Mac, and Linux operating systems. Screencast-O-Matic Apps provides free software that enables the user to record all views and motions 
of their monitor, even the motion of the cursor and click instructions, add explanations or comments, and is easy to use. Priowirjanto et al. (2013: 25) said that Screencast-O-Matic Apps was a software that could be used by the users of Windows $15 \mathrm{Xp}$, Windows Vista, and Windows 7 operating systems. ScreencastO-Matic Apps can also be used to record webcam activities, so any tutorial may be recorded and shared on YouTube or a blog.

Screencast-O-Matic Apps has great potential for the field of education because it is easy to use and provides simple ways of adding text. The videos created with Screencast-O-Matic can be viewed at any time and anywhere by anyone who has a browser and internet connection. Students can play video tutorials many times, so they can be used whether online, offline, or in hybrid study. The videos can serve as their reference materials. Generally, screencasts create a more interesting atmosphere in which to study online.

Suryanto (2014: 16) supports the previous statements. He says that Screencast-OMatic Apps is a software that can record all e-learning media for a tutorial video in which the teacher can teach the students as if they were in the classroom. Then, it can be shared through many models.

The researcher is interested in investigating the impact of the combination of a flipped classroom and Screencast-O-Matic on the teaching and learning process of reading skills in the Indonesian language. The findings provide new prospects and implications of the contribution of distance education in the educational system. In the following sections, the method, results and discussion, and conclusions are presented.

\section{METHOD}

This research is qualitative. According to Strauss and Corbin, as cited in Golafshani (2003: 600), qualitative research denotes research which obtains results without using statistical procedures. Meanwhile, the method used is case study. Case study is a qualitative research method that involves exploring the real object, then collecting detailed data using many sources of information and finally producing a descriptive report (Creswell, 2014).

This research is conducted at one of the private institutes in Bojonegoro, Indonesia. The participants are the second semester students of the Indonesian Language and Letters Education Department, and the teacher of reading skills in the Indonesian language. The data are collected through classroom observations and interviews. For the classroom observations, the researcher observes and records what is happening in the form of field notes. The interview adopts openended questions and the participants give open-ended responses.

The data are analysed using Creswell's thematic analysis. Creswell (2014) divides this approach into six stages of analysing and interpreting data. The stages are: 1) preparing, organising, transcribing the interview, and retyping the field notes, 2) coding, 3) using codes to make descriptions and themes, 4) representing the findings into a visual display, 5) interpreting the findings, comparing the findings and the literature, and mentioning the limitations, and 6) validating the accuracy of the findings by implementing the triangulation and reflexive procedures. 
After being analysed, the data are validated using triangulation. Triangulation refers to collecting a large amount information using many methods and sources (Cohen, Manion, and Morrison, 2007). According to Denzin, as cited in Humble (2009: 37) triangulation consists of more than one research method or data collection technique, i.e. triangulations of source, method, investigator, and theory. From the four techniques, the researcher takes triangulations of source and theory. In this research, the triangulations of theory consist of theories that strengthen the results, whereas the triangulations of source are obtained from the results of interviews and field notes.

\section{RESULTS AND DISCUSSION}

Based the observations in the flipped classroom, the teacher implements the steps of instructions in line with Bergmann and Sams (2012: 77), i.e. 1) what to do on the first day, 2) inform students about the flipped classroom model, 3) teach students how to watch and interact with the videos, 4) instruct students to ask interesting questions, 5) encourage students to help each other, 6) build an appropriate assessment system.

\section{What to Do on the First Day}

The researcher has interviewed the teacher of reading skills in the Indonesian language. The results show that reading skills in the Indonesian language includes: 1) the nature of reading, 2) reading as a process, 3) kinds of reading based on the audible sounds of the readers , 4) kinds of reading based on the range of texts, 5) steps in reading, 6) steps in pre-reading, 7) factors that influence reading skills, 8) the ways to improve reading skills, 9) the nature of literal reading, 10) method of literal reading, 11) the nature of inferential reading, 12) the nature of skimming and scanning.

The materials are then arranged and produced using Screencast-O-Matic Apps as outlined in the following steps.

1. Click 'Use FREE version' in the pop-up window to go to the home page of Screencast-O-Matic as shown in Figure 1.

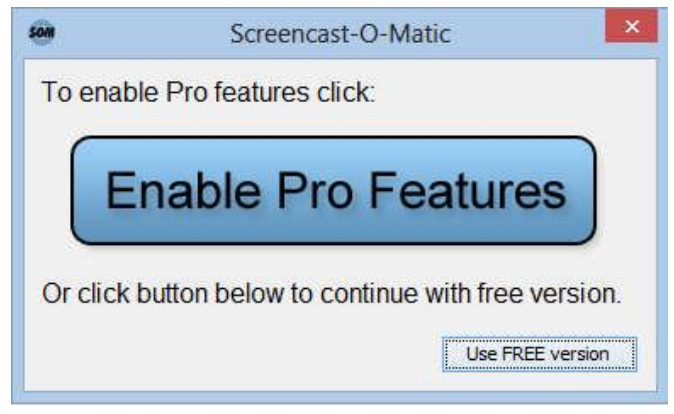

(a)

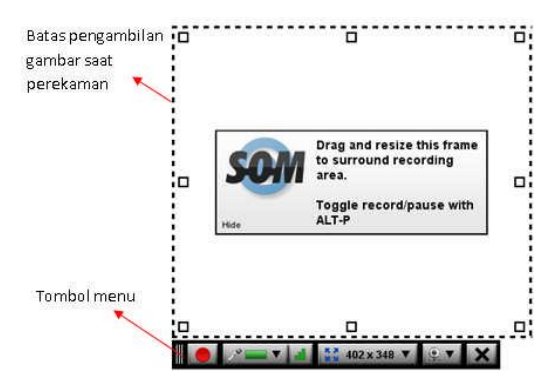

(b)

Figure 1 The home page of Screencast-O-Matic

Start the process using the following directions:

Click the record button; notice 'Go' appears. (The objects in Screencast-O-Matic Apps are shown in Table 1, below.)

Start the presentation. 
Click the done button when the recording has finished.

To see the result of recording, click the play button. You can save the file by choosing:

Publish to Screencast-O-Matic: Saving the file in Screencast-O-Matic web, where the public can play it if their computer has internet access.

Publish to YouTube: Saving the file onto the YouTube server, where users of YouTuber can play it.

Publish to video file: Saving the file onto local storage such as a hard disk or flash drive.

Set the file type of the video to be saved; MP4 format is recommended for a better result.

Set the size of the video.

Table 1 The objects in Screencast-O-Matic Apps.

\begin{tabular}{ccc}
\hline Object & Name of object & Function \\
\hline Record button & Starts to record \\
Pause button & Pauses the recording \\
Volume button & $\begin{array}{c}\text { Activates the microphone; if the } \\
\text { microphone is active, the indicator will } \\
\text { be up and down } \\
\text { Adjust the screen size }\end{array}$ \\
Sestart & Webcam button & Activates the webcam \\
\hline
\end{tabular}

\section{Inform Students about the Flipped Classroom Model}

The teacher must inform the students about the teaching model to ensure that they understand it fully. The students have to understand both what the teacher is doing and why he is doing it. Early in the implementation, there was some refusal from students, but as time has gone on, they have come to accept the flipped classroom.

\section{Teach Students How to Watch and Interact with the Videos}

When the file has been saved, the teacher uploads it to the browser. After that, the teacher asks the students to download it, and ensures that every student completes this step. This is the important step in the implementation of the flipped classroom. The teacher then demonstrates to the students how to watch the video. Additionally, he should encourage the students to be focussed while watching the video. Almost all of the videos are short, because longer videos mean that students will feel bored and not be able to focus on the materials.

\section{Instruct Students to Ask Interesting Questions}

To ascertain whether or not the students have watched the video, the teacher instructs them to ask him interesting questions. The question should be related to the material. There are interactions in the classroom between the students and the teacher, and among the students. They can ask questions either individually or in small groups. When the students ask questions to which the teacher does not 
know the answer, they work together on searching for the best answer. Based on the students' questions, the teacher infers what he has not taught clearly.

This instruction is very valuable for students who seldom interact with the teacher. In line with the findings of Bergmann and Sams (2012), the quiet, introspective students often have the same questions, but rarely voice those in the traditional model. In the flipped classroom model all students must ask questions. The researcher finds that the students are engaged because they can demonstrate their curiosity and learn in an individualised way.

\section{Encourage Students to Help Each Other}

Based on classroom observation, the researcher finds that the focus was no longer on teacher-centred learning, but rather on student-centred learning. The students automatically split themselves into groups and work together. They encourage interaction, collaboration, and exploration. They also realise that it is better to work as a team than to work individually.

In this stage, the teacher develops the flipped classroom method based on its initial letters, as shown in Table 2:

Table 2 The FLIP Acronym

\begin{tabular}{|c|c|c|}
\hline Letters & Acronyms & Meanings \\
\hline $\mathbf{F}$ & $\begin{array}{c}\text { Flexible } \\
\text { Environment }\end{array}$ & $\begin{array}{l}\text { Students can study the materials (videos) anytime and anywhere. This } \\
\text { means that the students do not need to be sat at their desk listening to the } \\
\text { teacher's explanation directly. }\end{array}$ \\
\hline $\mathbf{L}$ & $\begin{array}{l}\text { Learning } \\
\text { Culture }\end{array}$ & $\begin{array}{l}\text { This model is a form of student-centred learning. So, the students will } \\
\text { be more active in knowledge construction. }\end{array}$ \\
\hline I & $\begin{array}{l}\text { Intentional } \\
\text { Content }\end{array}$ & $\begin{array}{l}\text { The teacher implements the model so that students are more engaged in } \\
\text { the learning process and their cognitive understanding is developed. }\end{array}$ \\
\hline $\mathbf{P}$ & $\begin{array}{l}\text { Professional } \\
\text { Teacher }\end{array}$ & $\begin{array}{l}\text { The teacher has the role of observing the students, evaluating their } \\
\text { studies and giving feedback. So, he must be professional. }\end{array}$ \\
\hline
\end{tabular}

\section{Build an Appropriate Assessment System}

Each student comprehends the materials at a different level, and the main goal of teaching reading skills is growth. Students can be said to have good reading skills when they are able to reach the learning objectives: for example, they are able to understand the main idea of the passages they read.

Based on the observations, the researcher has analysed that 65 students have downloaded the videos from YouTube. In fact, the total number of students is 70 persons. It can therefore be concluded that 92 percent of the students are really motivated to study the videos as the learning materials. Meanwhile, the teacher acts as the facilitator in the classroom. Students are eager to discuss and present their arguments. Based on the students' opinions given in the interview process, they are truly motivated and able to enjoy their leisure time greatly.

The findings are in line with Bergmann and Sams (2012), who say that various models of assessment are available to the educator. In this case, the teacher evaluates the students individually and in groups. He assesses them on an A-D grade scale. The students who get $\mathrm{C}$ and $\mathrm{D}$ grades can take remediation provided by the teacher. This has been established to support students in mastering reading skills in the Indonesian language. 


\section{CONCLUSION}

Screencast-O-Matic contributes to the successful implementation of the flipped classroom. This combination produces innovation in the teaching and learning process of reading skills in the Indonesian language. The teacher's role in the learning process is as a facilitator, resulting in some good impacts for the students: 1) the students are motivated to have the learning materials in videos, 2) the students are able to enjoy their leisure time, 3) the students are pleased with the teaching and learning process and are able to answer questions quickly, 4) the students appreciate each other's opinions, and 5) the students have more comprehensive knowledge of the Indonesian language reading skills materials.

Other teachers who interested in adopting the flipped classroom are advised to talk to their students, get to know them as the amazing people they are, learn how they think, and help them learn how to learn. The teacher must provide the right assessment for each student. Because teachers know their students well, and because they know to what extent students understand each learning objective, they can vary their questions based on student understanding. Each student is at a different level of comprehension, and the main goal is growth. Implementing the flipped classroom will help teachers to enable their students to meet their individual learning needs.

\section{ACKNOWLEDGEMENT}

We would like to thank Kemristekdikti, who has fully funded this research.

\section{REFERENCES}

Bergmann, J., \& Sams, A. (2012). Flip your classroom: Reach every student in every class every day. Washington, DC: Internal Society for Technology in Education.

Braun, B., Bremser, P., Duval, A. M., Lockwood, E., \& White, E. (2017). What does active learning mean for mathematicians? Notices of the AMS, 64(2), 124-129.

Chandra, F. H., \& Nugroho, Y. W. (2016). Peran Teknologi Video dalam Flipped Classroom. Jurnal Dinamika Teknologi, 8(1), 15-20.

Cohen, L., L. Manion, and K. Morrison (2007). "Research in Education Sixth Edition" Journal of Research in Special Educational Needs 13: 7 - 14.

Creswell, J. W. (2014a). Penelitian Kualitatif dan Desain Riset. Yogyakarta, Indonesia: Pustaka Pelajar.

Creswell, J. W. (2014b). Riset Pendidikan: Perencanaan, Pelaksanaan, dan Evaluasi Riset Kualitatif \& Kuantitatif. Yogyakarta, Indonesia: Pustaka Pelajar.

Golafshani, N. (2003). Understanding reliability and validity in qualitative research. The Qualitative Report, 8(4), 597-607. 
Humble, A. M. (2009). Technique triangulation for validation in directed content analysis. International Journal of Qualitative Methods, 8(3), 34-51.

Johnson, G. B. (2013). Student perceptions of the flipped classroom (Master's thesis). Okanagan, Canada: The University of British Columbia.

Priowirjanto, Yudha Prapantja, et al. (2013). Materi simulasi digital. Southeast Asian Ministers of Education Organization Regional Open Learning Centre.

Rakhmetullina, S., Uvaliyeva, I., \& Nugumanova, A. (2014). Information system of educational statistics as a tool for quality management in education. Global Journal of Information Technology, 4(2), 132-137.

Suryanto, H. (2014). Pengembangan Multimedia E-Learning Berbasis ScreencastO-Matic dalam Pembelajaran Matematika. Jurnal Ilmu Sosial dan Humaniora, 1(1), 15-20.

Tarigan, H. G. (2008). Membaca Sebagai Suatu Keterampilan Berbahasa. Bandung, Indonesia: Angkasa Bandung. 